\title{
Desenvolvimento de veículo solar usando prototipagem rápida
}

Isabela M. de Oliveira (EM), Mariana Scompari (EM), Daniel F. Zambon (EM), Layssa E. Duarte (EM), Gabriel F. de Medeiros (EM), Marcelo Maialle (PQ), Rodrigo Baldo (PQ), Eduardo Okabe (PQ), Natália B. de Mendonça (IC), Aline A. da Costa (IC).

\section{Resumo}

Nosso projeto é a prototipagem rápida com o desenvolvimento de energia limpa, usando um protótipo de um carro movido à energia solar, feito através da impressora 3D.

Palavras Chave: Prototipagem rápida, automação, energia solar.

\section{Introdução}

O projeto tem como proposta desenvolver um carrinho movido à energia limpa, com o objetivo de diminuir os danos ou modificações causados ao meio ambiente, provocados pelos gases de efeito estufa e o aquecimento global.

\section{Resultados e Discussão}

O projeto foi separado em duas etapas. A primeira etapa consiste no manuseio dos programas Inkscape e Qcad, para confeccionar os desenhos gráficos, e posteriormente imprimilos na impressora 3D.

Na segunda etapa iniciou-se a construção do protótipo do carrinho. Os materiais utilizados foram: canos de PVC, rodas feitas pela impressora 3D e o motor para a engrenagem.

O protótipo passou por varias modificações desde o início de sua construção.

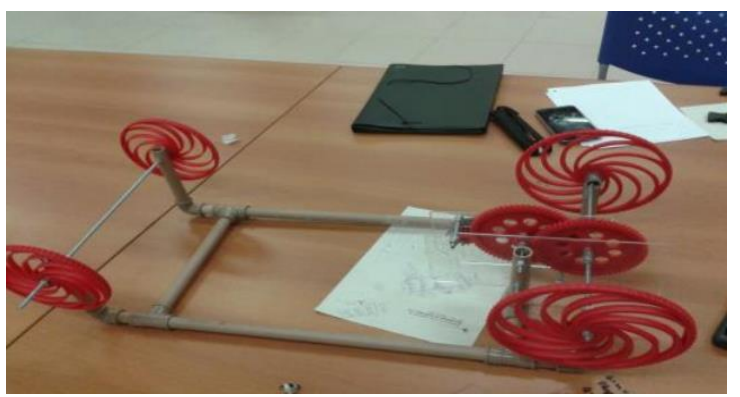

No final, instalou-se junto à placa de aquecimento solar a engrenagem do carrinho. Após testar o carrinho, expondo-o a luz solar para seu funcionamento, o projeto poderá ser concluído.

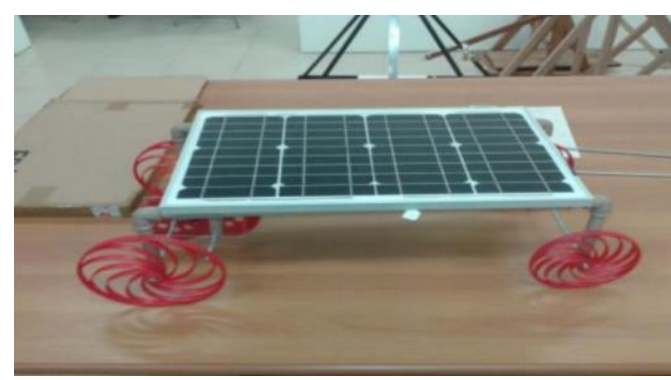

\section{Conclusões}

Foi concluído que a utilização de energia solar reduz a emissão de gases poluentes causados pelo uso do petróleo como combustível, além de ser uma energia renovável e limpa, necessita de pouca manutenção.

\section{Agradecimentos}

Gostaríamos de agradecer aos professores Marcelo Maialle, Rodrigo Baldo e Eduardo Okabe da FCA que nos orientaram durante o projeto, a nossos familiares pelo apoio e as monitoras Natália Mendonça e Aline Andrade que nos auxiliaram no desenvolvimento do projeto.

1 Arquivo pessoal do projeto

Pigatto,Bruno André Selivon Ciencias da Natureza. Curitiba, Paraná, Brasil. Disponível em:

http://natuscience.blogspot.com.br/2011/04/construcaoefuncionamento-de-um-carro.html 